\title{
Engines for Peace? Extractive Industries, Host Countries, and the International Community in Post-Conflict Peacebuilding
}

\author{
Päivi Lujala1, Siri Aas Rustad², Sarah Kettenmannn ${ }^{3,4}$ \\ ${ }^{1}$ Department of Geography, Norwegian University of Technology and Science (NTNU), Trondheim, Norway \\ ${ }^{2}$ Peace Research Institute Oslo (PRIO), Oslo, Norway \\ ${ }^{3}$ Environmental Law Institute (ELI), Washington DC, USA \\ ${ }^{4}$ Beveridge \& Diamond, New York, NY, USA \\ Email:Paivi.Lujala@svt.ntnu.no,sirir@prio.no,skettenmann@bdlaw.com
}

Received 28 March 2016; accepted 14 May 2016; published 17 May 2016

Copyright (C) 2016 by authors and Scientific Research Publishing Inc.

This work is licensed under the Creative Commons Attribution International License (CC BY).

http://creativecommons.org/licenses/by/4.0/

(c) (i) Open Access

\begin{abstract}
Extractive industries can provide great opportunities for post-conflict peacebuilding in resourcerich countries by providing revenue to finance reconstruction and set the economy back on track. However, the process of resource extraction often poses challenges for peacebuilding. This article first explains the various challenges that valuable natural resources can pose in post-conflict countries, and establishes a typology of post-conflict contexts where extractive industries, the host country, and the international community can play primary roles as peace promoters. It then elaborates on the specific roles each of these actors can play: i) what approaches are available for responsible companies that aim to be peace sensitive and even promote peace and development locally and nationally; ii) how a country that has some capacity and political will to secure long term peace and development can promote responsible exploitation; and iii) how international actors can promote responsible company and government behaviour in countries with low capacity and willingness use the natural resource base for the best of its whole population.
\end{abstract}

\section{Keywords}

Peacebuilding, Natural Resources, Management, Extractive Industry, Peace Promoter

\section{Introduction}

Many post-conflict countries possess high-value natural resources, such as oil, gas, timber, gemstones, and other

How to cite this paper: Lujala, P., Rustad, S.A. and Kettenmann, S. (2016) Engines for Peace? Extractive Industries, Host Countries, and the International Community in Post-Conflict Peacebuilding. Natural Resources, 7, 239-250.

http://dx.doi.org/10.4236/nr.2016.75021 
valuable minerals, which can play a decisive role in economic recovery and peacebuilding. In many of these countries primary commodity exports account for the lion's share of total exports, providing often more than $30 \%$ of GDP and over 50\% of the national budget [1]. For example, Angola's crude oil and diamonds accounted for over $90 \%$ of all exports, over $70 \%$ government revenues and almost $60 \%$ of the nation's GDP in the years following the end of conflict in 2002 [2]. Other examples of post-conflict countries rich in-and dependent onnatural resources include Iraq, Sierra Leone, Liberia, Sudan, South Sudan, Democratic Republic of Congo (DRC), Timor-Leste, and Algeria.

These resources provide a great potential for revenue and development. In the peacebuilding process, extractive industries can play an important role in realizing revenues from highly valuable natural resources and bringing direct foreign investment into the country. In short, extractive industries are a key contributor to the economic boost natural resources can provide to post-conflict countries. Without these companies the resources would, in many cases, remain underutilized. In addition to contributing to national recovery and reconstruction, the presence of extractive industries can indirectly support peace processes at the local level by providing local people tangible peace dividends, for example, in the form of new income sources, jobs, improved infrastructure, and even helping to meet basic needs.

Peace brings with it both expectations and demand for development and prosperity, and the opportunity provided by high-value natural resources places great pressure on donors, post-conflict governments and the extractive sector to get mining and exploitation underway [3]-[7]. Further, natural resources and extractive industries also provide a promise of lucrative profits to well-positioned individuals, groups and companies. In an ideal world we would like to see responsible companies operating in post-conflict countries where the government takes seriously its responsibility to manage, preserve, and exploit its natural resources and has the will and capacity to use the ensuing revenues in an accountable manner and for long term development.

Unfortunately, this is often not the case. More often than not, high-value resources have been a curse rather than a blessing for countries with limited institutional capacity, and especially in countries recovering from armed conflicts [5] [8]-[10]. Policy choices by both government and companies too often undermine the peace process: Companies may find themselves operating in countries where political elites divert rights to resources and resource revenues to small groups or to prestige projects that do not serve the interest of the ordinary citizens. Corruption might be rampant within government ministries, regulatory institutions, and local communities alike. The legislative framework concerning resources and resource exploitation is often little developed, weak, skewed to benefit one party over another or not enforced. The environmental standards can be lax or completely lacking, and the local people may be excluded from the decision-making processes. Some companies seek to exploit these types of situations; others take their corporate social responsibilities more seriously, but may be hampered by the government from establishing good practices or forced to work around corrupt officials.

The fact that valuable natural resources can both promote and challenge peace in post-conflict countries has been largely ignored in resource curse literature as well as in the wider research into peace and conflict [10]. In the following pages we discuss challenges valuable natural resources pose for peacebuilding in post-conflict countries and some possible policy options for post-conflict countries that are attempting to build peace amidst rich natural resources. We start by briefly stating why the extractive sector has a special role in the post-conflict context and why high-value resources pose such a challenge to peace. We then briefly present our framework for the main discussion, which focuses on i) what approaches are available for responsible companies that aim to be peace sensitive and even promote peace and development locally and nationally; ii) how a country that has some capacity and political will to secure long term peace and development can promote responsible exploitation; and iii) how international actors can promote responsible company and government behavior in countries with low capacity and willingness use the natural resource base for the best of its whole population.

\section{Why Are High-Value Resources and the Extractive Sector a Challenge for Peace?}

When peace comes to a country rich in high-value natural resources, extractive industries are among the first foreign investors to enter or return to the country. These companies have little to no flexibility in where their business may be located and must consequently move to where the oil, gas, metals, and minerals lie underground. For these companies, countries that move from war to peace can offer vast, untapped sources for exploitation. Good margins and the advantage of being among the first to secure the most lucrative rights can lead to a race in which issues related to transparency, corporate social responsibility, expectation management, and environmental and social consequences may be side-stepped by the companies, or used strategically to obtain 
operating licenses and concessions.

Similarly, governments may also be inclined to get extraction underway as rapidly as possible and to grant permissions without adequate processes to assess the consequences, to include local society in the project, and to ensure good contracts with the extracting company. Transitional and elected post-conflict governments and international development agencies alike encourage the introduction or reintroduction of private businesses and corporations that are able to invest quickly and generate revenues shortly after, and often even before the operations commence (for example, through payments for exploration grants and concession rights, signing bonuses, etc.). Further, authority figures in power during interim or transitional governments may be tempted to grant exploration and exploitation rights to dubious companies soon after peace to reap benefits before more accountable governments are established by election. Thus, post-conflict countries may need to deal with contracts signed by previous governments, transitional governments, or rebel groups, in which the short-sighted interests of the few may have trumped the long-term development needs of the population as a whole. For example, in DRC, the state had granted mining companies tax exemptions for periods up to 30 years during or immediately after the two Congo Wars (1996-1997 and 1998-2003) [11]. Thus the Congolese state and people were deprived of important fiscal revenues.

The lack of enforcement mechanisms in place to monitor existing laws and regulations can jeopardize even the best intentions. Governments might be unable to secure the appropriate means needed to realize and enforce existing laws. These means might include training of local law enforcement officials or judicial authorities. Individuals who were trained before the conflict may have left or may not be accustomed to the new legal system in place.

At the local level, competition over access to resources—-which may include established residents, returning refugees, displaced persons, ex-combatants, and migrants—may spark tensions over overlapping claims, unclear rights to resources, and differing views on which entities have the authority to grant resource rights and access. Such tensions may be further aggravated by environmental damage related to resource exploitation. The resulting disputes between communities, various levels of government, and extractive firms can undermine, destabilize, or even derail the peacebuilding process.

Besides opening up a valuable and contested playground that creates special challenges in the peace process, valuable natural resources and conflict are often interlinked in the first place [9] [12]-[14]. In worst case, the rush is after the very same natural resources that played a role in the conflict. Abundant resources directly affect and even cause conflict as they increase the value of state capture and encourage resource-rich regions to seek greater autonomy or outright secession. Resources are also used to finance warfare and can be looted for private enrichment during the conflict. Finally, valuable natural resources may also increase the risk of conflict indirectly through their negative impact on economic performance and institutions [15]. Thus, high-value natural resources make it more difficult for these countries to build sustainable peace; conflicts in which natural resources played a role have a higher likelihood of relapsing than other conflicts [16]. Therefore, it is essential that the governments, companies and the external actors consider the linkages to conflict when designing policies for management of valuable natural resources [8] [17].

\section{Discussion Framework}

The post-conflict context is often very chaotic, and complex, with many actors. To simplify we have created a framework that describes who the main peace promoters are depending on the post-conflict context. There are four different categories, based on the performance of the government (bad-better) and how responsible the extractive company operating in the country is (less-more) (Figure 1). This is, of course, a very crude simplification, and it is possible that the quality of a country's governance can improve or worsen over time, and that a single country can have a combination of more or less responsible companies. Nonetheless, this framework allows us to more clearly discuss the roles that can be played by the actors considered in this articletional community, governments and companies - under different circumstances.

Managing natural resource extraction and operating in a post-conflict country is a challenge both for companies and governments. Ideally, a company will seek to promote peace — or at least to be peace neutral—through its operations in a country where good governance is established or in the making. In this context, both the company and the host government can be seen as the main peace promoters (top-right corner in Figure 1).

The world rarely is ideal in these respects, especially in post-conflict countries. Unfortunately, too many companies show little consideration to peacebuilding work. Some extractive industries maintain corrupt, non- 


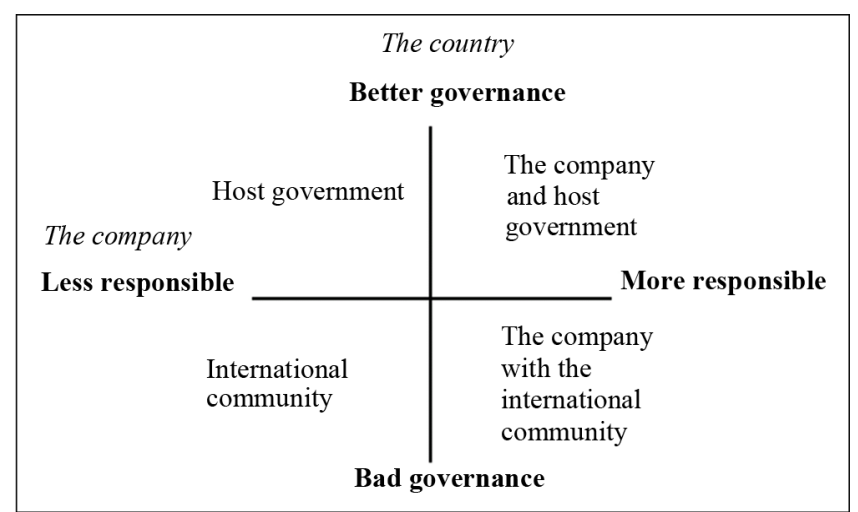

Figure 1. Main peace promoters under different peacebuilding contexts.

transparent, or unsustainable practices, taking advantage of communities unprotected by laws, or even [un]knowingly contributing to tensions among conflicting communities, thereby fuelling the relapse of conflict. Sometimes such companies operate in countries that seek to establish better institutions or have a high level of political will to promote decent company behaviour. In this context, the host government will have to take on the role of the main peace promoter (top-left corner in Figure 1). This was the case in Liberia after President Sirleaf Johnson came to power in 2006. She annulled all timber contracts dating from the (pre-) conflict time and renegotiated better contracts with some extractive industry companies that increased the government's share of the revenues as well as improved working conditions for the employees [8] [18] [19].

In other cases, companies wanting to promote high ethical standards may face barriers from governments less concerned with promoting long-term peace, economic growth, and decent behaviour. In these cases, the company itself together with the international society must take responsibility to promote sounder resource management (bottom-right corner in Figure 1). This is often challenging in hostile environments. In the case of Chad, for example, a consortium of oil companies together with the World Bank set up a system to ensure a more transparent and fair use of the revenue from the newly started oil production. However, the system became instead a tool for the country's dictator to gain control over the resources: In 2000 Chad was an illiberal, conflict-ridden country without oil; today it is an illiberal, conflict-ridden country withoil. The main things that have changed are that the benefits of retaining power are vastly higher, and that the government now has the money to buy arms ([20], p. 333).

The worst case scenario is a post-conflict country where the regime has little ability or willingness to manage the valuable natural resources in a good manner and to regulate the operations of extractive industries, and where the extractive industry companies operate without regard to corporate social responsibility and the special challenges posed by the post-conflict context. In this instance, it may only be the international society that has the capability to monitor companies through promoting and enforcing, for example, international standards on good company conduct, revenue transparency, and commodity tracking systems and to compel the government to engage in policies that can promote better management of the natural resource base and the revenues its receiving from the extractive companies (bottom-left corner in Figure 1).

In the following sections we elaborate on some of the key roles the company, the host government, and the international community can play when they are in a position to be the main peace promoter.

\section{The Companies as the Peace Promoters}

Although it is widely accepted that business of business is business, there is a debate about to what extent firms should be actively promoting peace or even reacting when states fail to exercise minimum standards of governance. In any case, in recent years several extractive companies have come to realize that to secure long-term profitability, and to build their reputations, they need to establish themselves as a "responsible" company. Consequently, an increasing number of companies are starting to take their ethical responsibilities more seriously and engaging in corporate diplomacy [21]. However, in many post-conflict countries, laws and regulations are in a state of flux. Relevant laws may not be in place, may conflict with one another, or may be holdovers from the 
interim or pre-conflict government period, adding to general confusion about how the legal framework will develop, which laws are to be followed, and which ones are to be enforced. In these situations, businesses can find it difficult to follow the rules and conduct ethically sound operations. It is not uncommon that the conditions set by the government, such as deadlines, hamper companies' ability to make thorough environmental and social assessments.

Extractive companies operating in the post-conflict context must give special consideration to several aspects of their business. For example, they may be subject to a concession review or cancellation process by the interim or post-war government, and may need to assist in developing a credible concession process. Sometimes the companies may need to adhere to global initiatives such as the Kimberley Process, EITI, or Voluntary Standards (which will be described later in this article) because the home or host country or an investor requires it. However, not all countries or investors require this. In the absence of larger initiatives, one of the important things extractive companies can do is to develop their own principles of transparency and conduct extensive environmental and social assessments with regard to their operations, contracts, and revenues regardless of whether they are required to do so or not.

Within their local areas of operation, the companies need to take into consideration local livelihoods that depend on small-scale mining which can be unofficial and even illegal. In some cases, small-scale exploitation of valuable natural resources, such as diamonds or forest products, may have developed as a coping strategy during conflict and can be the economic backbone of war-torn communities. Local populations may accordingly view any disruption of their livelihoods, through large-scale exploitation, as a negative side effect of peace and feel strong resentment towards the companies operating in the area. These can be compounded by the fact that the when state institutions lack capacity and effectiveness, as they often do in post-conflict situation, the local populations may adhere to local traditions and customary laws that may be in conflict with national law.

Thus, the businesses may need, and should be encouraged, to develop both legal and social licenses to operate, and when local populations are excluded from negotiations, firms bear the burden of seeking a "social license to operate" from local communities [22]. In areas where state governance is lacking, weak, or corrupt, traditional religious or customary leaders may play stronger roles in governing local communities. If extractive industries do not recognize this cultural institution within the region in which they operate, they may intensify tensions with local communities or within local groups. At same time, the companies, by being too sensitive to local traditions, may unintentionally cement local power structures that marginalize substantial segments of the local people, for example, by letting the local elites take over the negotiation process and accrue the most benefit from the company's operations, services or revenues it generates in the community. This means that the companies need to carefully assess the local context to design approaches that are effective and that promote equity. This is especially demanding in war-affected mining areas as these communities, and the marginalized groups in particular, often bear a double burden: the effects of the war and the effects of the project. Consequently, the capacity of the local people may not be large enough to participate and advocate their interest. It can be the case that the company needs to facilitate building up the local capacity and competence before they can even start to negotiate the social license.

Extractive industries that were in the region before or during the conflict need to directly address past grievances of local communities surrounding wealth sharing, recognition of land claims, and environmental degradation, especially when these played a role in causing or sustaining the conflict [22]. Unless these are addressed satisfactorily, reopening of a mine can be impossible, as was the case in Bougainville, Papua New Guinea (PNG), where the Panguna copper mine was central in the conflict between the central government and island population (1989-1999) and still to date has not been reopened.

Also companies that arrive to conflict-ridden regions where there has not been extraction before need to take into account the conflict in their relations with host-community. In post-conflict Guatemala, the Marlin mine owned by the Canadian mining company Goldcorp was regarded by the international community as a great opportunity for economic development and livelihoods recovery. However, the neighbouring communities of the gold and silver mine were inherently distrustful and resistant of the project, citing past grievances and violence that were never addressed [22]. This is an example of a case in which extractive companies' operations in newly "opened" countries foment chronic distrust among local communities and the government. Trust building thus becomes a key element of company-community relations, for example, through multi-stakeholder groups including civil society, (local) government and the extractive industry.

One option the companies have is to provide social services to, or even share revenues with, the local com- 
munities, either because the government is not able to provide this or to buy good-will among the population [23]. In cases where the state fails the population, the company may even have a moral obligation to do so [24]. However, these services may cause more harm than good in the long run and should thus be considered carefully [23] [25]. These types of schemes can create a dependency relationship between the local community and the company, making a break-up of the company problematic for the community as the services provided are not sustainable without the company's presence. In addition, such a relationship could further deepen the distrust between the government and the local population, taking away the responsibility of the government to deal with the situation in the area and as the provider of services and infrastructure to the population.

\section{The Government as the Peace Promoter}

Things brighten when there is political will at the top level or the institutional set-up is partially functioning. This is reflected in the top-left corner in Figure 1. The challenges may be as huge as in any other post-conflict country: flight of competent personnel, lack of resource base assessments, war-time mining, pressure to get revenues flowing, etc. However, a range of approaches to more effective and sound natural resource extraction become more feasible when there is more capacity and political will to push for reforms and follow them through. It is important to ensure that new extraction contracts follow the best practises and that the host county secures a fair share of the revenues. Equally, attention needs to be paid to review and renegotiate existing extraction contracts. To combat corruption and patronage, and to increase the revenue flows to the state, a key approach is to design and implement mechanisms for transparency and accountability. This means that there should be full openness and disclosure from both the government and the company about contracts, revenues and operations.

\subsection{New Contracts}

Contracts and concessions are important tools in managing natural resources and a key instrument in determining the government's share of the generated revenue flows. Poor contracts and concessions do not only deprive the state of revenues, they may also result in unsustainable or too rapid extraction, using extraction methods that are wasteful, exploiting people, and destroying the environment. Poor contract terms may foster corruption and give extractive firms too much power in the country's internal affairs.

Poor contracts may also undermine the state's legitimacy in the eyes of the population, if the contracts create the impression that the state is corrupt or incapable of looking after the natural heritage of the country. In addition, many post-conflict governments enter in the negotiations as the weak party: They often have a less precise estimate of the real resource base than the companies themselves. This combined with the urgency of time and large risks related to large investment projects, results in negotiations conducted under unequal terms.

The legal framework concerning natural resource management or contracts and enforcement of the existing laws and regulations may be outdated or outright absent. Therefore, it can be in the country's best interest to impose a moratorium on new contracts until appropriate processes for negotiation, award, and follow-up are in place, including environmental and social standards and safeguards for extractive industries [17].

\subsection{Concessions Reviews}

Many post-conflict countries inherit contracts that grant extractive companies unduly high profit margins, generous tax exemptions, or other benefits. Often they have been signed under conditions that lack transparency and accountability, may have not been approved by local communities, and may fail to stipulate appropriate environmental and social standards. Such contracts can not only lead to significant losses of public revenues, but can also generate grievances, tensions, and even violence.

The contracts may have been signed by pre-war governments, war-time governments that were under pressure to finance the warfare or by rebel groups, and they may no longer, or never were intended, to serve the best interest of the nation; they may have even been signed to derive personal benefit from the exploitation [18]. Transitional governments, on the other hand, may have worked under short time-horizons and pressing needs, and may have attempted to direct financial benefits to small groups or to secure their place in the upcoming elections. To cope with such contracts, the government can engage in reviews, where the contracts are evaluated against set of criteria to ensure legality, profit sharing, and taxation, and those found non-compliant need to be cancelled or renegotiated [18] [19]. 
An example of a successful review round can be seen in Liberia, where the Liberian government, under international pressure, initiated a review of all timber concessions after the end of the civil war [7] [8] [19]. The review concluded that all timber concessions were illegal, which was followed up by President Ellen JohnsonSirleaf who cancelled all forest concessions as her first executive order. In addition, the President and a government negotiations team comprised of participants from the Ministry of Lands, Mines and Energy and the Ministry of Agriculture reviewed and redrafted contracts with the two international giants Arcelor Mittal and Firestone [26]. The new contracts included a better deal for the government by using market price to determine the price of the iron ore, as well as increasing the lease price for Firestone. Further provisions on tax holidays, health care for workers and improved housing for workers were also included.

A similar review attempt was made in the DRC following the two civil wars (1996-1997 and 1998-2003) to assess mining contracts that were signed during the wars. In 2005, the Lutundula commission, an investigative panel aimed to uncover fraud in wartime contracts, recommended renegotiation and cancellation of sixteen contracts and judicial investigation of 28 Congolese or international companies. However, in contrast to Liberia, the commission's report was not addressed by the DRC president, government and parliament, and was quietly buried [18].

The experience of concession reviews in Liberia and DRC demonstrates that political will is crucial to make such reviews effective. In Liberia, President Johnson-Sirleaf showed clear political will from the top level of governance to deal with corrupt contracts and concessions. In DRC, on the other hand, the Lutundula commission struggled to get both political and economic support at the national level to conduct the review and set the results in action.

\subsection{Transparency Initiatives}

The extractive industries can also pose challenges to peacebuilding if they do not honestly report their earnings and expenditures and transfers to government. Lack of trust and openness in revenue streams from the companies to the government can lead to increased corruption, thus depriving the people for the revenues from the resources [27]-[29]. But it may also lead to false allegations of corruptions because the expectations related to the revenues are too optimistic among the public, which can stir unnecessary tension [30]. By providing information publicly it is possible to set spotlight on companies' activities, revenue sharing between companies and the state, and the state's use of revenues.

Several initiatives promote transparency within the extractive industry sector. Among the first initiatives was the civil society initiative Publish What You Pay (PWYP), which seeks to establish legal instruments such as stock exchange rules to achieve mandatory transparency of revenue flows between extractive companies and the host government. However, it is hampered by its voluntary nature and lack of host-country engament. An initiative that demands commitment from the host-government is the Extractive Industry Transparency Initiative (EITI). EITI is a framework that a country adopts in order to force its own agencies and the extractive companies to report revenues. Countries intending to implement the EITI need to go through a process which includes engaging the extractive industry and civil society in a multi-stakeholder group, production of annual EITI reports, and adoption of EITI standard. The validation as a compliant country has to be renewed every third year. The EITI Reports, which are compiled by an independent organization, include information about how much the companies have produced and paid to the government, and also disclose how much the government reports to have received in revenues from the companies. These reports may also include other aspects of natural resource governance such as recommendations for reforms.

The underlying theory of change for the EITI is that the disclosure of revenues should inform, raise awareness and empower the public to use this information to hold the government accountable for their spending and for receiving a fair share of revenues. EITI has made real advancement in making formerly hard-to-come-by information public, although its impact on corruption and other broader outcomes is contested [31]. Nonetheless, the efforts by the EITI, PWYP and other similar initiatives have made revenue transparency increasingly an international norm, and most initiatives now extend transparency to other aspects of natural resource governance [32]. With regard to EITI, some countries have made the EITI to extend beyond the minimum EITI requirements, for example, by including forestry (Liberia), requiring reporting at the sub-national level (e.g. Nigeria and Ghana), and listing publicly the benefiting owners behind the extractive companies (Liberia and DRC) [33]. With time, some of these are becoming institutionalized within the EITI standard. The new 2016 EITI Standard now demand that the future EITI reports include a much more detailed level of revenue reporting, such as disaggrega- 
tion at the company level, which further puts pressure on the companies [34].

A country emerging from a conflict may not be able to implement EITI or other comprehensive transparency scheme at the start. However, it is important to include transparency as a principle in all new and reformed natural resource management institutions and regulations.

\section{International Community as the Peace Promoter}

When neither the company nor the host government is in a strong position to act as peace promoter, the international community may be able to play a role. In these situations, the outside pressure on companies becomes the main driver to ensure that companies follow decent standards with regards to corporate social responsibility. Donors, international organizations and financial institutions can attempt to curtail illegal exploitation and promote good company behaviour, for example, by enforcing commodity tracking systems and making financing to extractive industries conditional on some minimum requirements or imposing home-country legislation that require the operating companies to follow certain rules. In addition, in the wake of conflict, the international community may have a unique chance to push extractive sector reforms in the affected countries that can have long-lasting positive effects.

\subsection{Commodity Tracking}

One of the first tasks after a conflict ends is to curtail the access to resources looted during the conflict to finance warfare or personal gain. As peace is fragile in the beginning, some groups, so-called "peace spoilers" may actively seek to destabilize it and seek opportunities to finance renewed conflict. Other individuals or groups may use the chaotic situation to engage in, or to continue, illegal resource extraction. Companies that choose to trade commodities from such groups may intentionally or non-intentionally promote continued unrest and violence. This has been the case, for example, in the eastern part of DRC over the last decade.

The international community has established several initiatives to curtail this type of trade. By tracking the resources from the site of production to the end buyer, the buyers are able to choose non-conflict minerals, and thus the market and economic profit for trading with conflict minerals is decreased. One of the more well-known revenue tracking systems is the Kimberly Processes Certification System (KPCS). This was established in 2003 as a collaboration between national governments, the diamond industry and civil society. The aim has been to prevent diamonds from financing conflict, as was the case, for example, in Sierra Leone and Angola, by requiring that each diamond parcel have a certificate which traces the diamonds to its mining site.

The KPCS is a global, multi-stakeholder initiative, and its success has in recent years been hampered by its heavy, consensus seeking structure. Therefore, it can be more fruitful to establish commodity tracking schemes that are narrower in scope. An example is the Tin Supply Chain Initiative (iTSCi) of the International Tin Research Institute, an industry-based scheme developed in 2010, which is designed to track the supply chain for tin in the eastern DRC, from the mining site to the export point in Burundi and Rwanda.

One way to regulate extraction and trade is through companies' home country legislation or international legislation, an approach that PWYP is promoting. When the post-conflict country fails or is unable to guarantee "conflict free" exploitation, international agreements or home-country legislation may step in and compel the companies operating or importing from post-conflict countries to prove that their commodities come from legal sources and that mining or the trade does not contribute to (potential) armed groups. An example of home-country legislation that seeks to restrain companies' operation in conflict prone area is the Section 1502 of Dodd-Frank Wall Street Reform and Consumer Protection Act from 2010. It requires companies trading on Wall Street that import certain minerals from DRC and bordering countries to publicly provide details on their chain of supply.

Another attempt to control companies operating and importing from fragile areas are OECD's Due Diligence guidelines that were developed to assist firms to protect human rights and avoid contributing to conflict. The guidelines specify a number of actions that firms should undertake when operating in conflict-affected or highrisk areas, including suspending trade with dubious suppliers, using leverage over suppliers to compel them to adhere to the standards, working together with the local authorities to impose and enforce standards, and following up breaches.

\subsection{International Standards}

Because companies may underestimate the complexity of operating in post-conflict situation or be unaware of 
the far-reaching consequences of their operations and may thus conduct only superficial assessments or only consider environmental consequences, the international community can step in by creating standards for responsible and peace sensitive operations [35]. In post-conflict situations, companies must be particularly conflict sensitive, even in the cases the natural resources or the extraction site have not been part of the conflict [22]. For example, Goldcorp that started gold and silver extraction in post-conflict Guatemala in 2004 faced several challenges stemming from the post-conflict environment even when neither the mine nor the company had anything to do with the Guatemalan civil war [22]. While tensions over land and other impacts on local communities are issues that often surface in mining areas, the social consequences of the conflict often make these particularly acute.

Banks and other investors have come to realize that impacts of extraction and tensions over extraction damage both natural and social environment, exposing extraction projects to unnecessarily high risks. The result is that the investors are more and more often seeking to subject the companies to more thorough and broader assessments both prior to and during the project establishment. Therefore, World Bank, International Finance Corporation, commercial banks and US and UK governments have been among the actors that have promoted and developed international standards to help extractive companies to engage in responsible natural resource exploitation, which are more and more adopted by companies like Goldcrop [35]. These include initiatives such as Voluntary Principles on Security and Human Rights by U.S. and UK governments [36]; Equator Principles by a group of ten commercial banks [37]; and International Finance Corporation’s Performance Standards on Social and Environmental Sustainability [38].

These types of standards aim at identifying and managing environmental, social, and security concerns in mining areas. Although the standards have often not been developed specifically for post-conflict settings in mind, they are relevant to peacebuilding because, among other requirements, they call for the investors and companies to evaluate, monitor, and respond to risks to the environment, land rights, migration, employment, and security. The idea is that banks and other institutions that finance investment on natural resource extraction have leverage over companies to compel them to follow set of best practices.

\section{Concluding Remarks}

Resource-rich post-conflict countries are distinguishable from other post-conflict countries because they possess an internal financing source for post-war reconstruction and a potential base for economic growth. This significant opportunity is counterweighted, however, by the daunting challenge of managing these resources, their exploitation, and the revenues. This article has discussed the challenges that valuable natural resources pose to peacebuilding and the approaches that the extractive industries, the governments, and the international community can use to promote a durable, transparent business and management of natural resources and their revenues in the wake of conflict.

It is critical in the post-conflict context that the company maintains transparent relationships with all players, including government, local communities, and donors. When revenues have reached the government there is a need for a stable, equitable and fair distribution. This is normally not something that the extractive industry should actively monitor. On the contrary, this should be a national matter. However, it is important to distinguish between revenues that are transferred to the government - in other words, revenues to be used for development, rebuilding the economy, and so forth-and compensation paid to the local population due to land expropriation and environmental degradation as a consequence of the extraction. The former is the responsibility of the state, while the latter may be that of the companies.

A range of approaches to more effectively harness and govern the resource base and the revenues from the extraction becomes more feasible when there is more capacity and political will to push for reforms and follow them through in the country. For example, governance is more efficient when assessments, reporting, openness and transparency are no longer voluntary, but required.

The international community has often less direct influence on the resource-rich countries' governments as they are less dependent on donors and international financing institutions such as USAID and IMF. However, the end of conflict opens up an opportunity to push reforms as revenues from the resources are not yet accruing and the donor leverage is at its highest and donor conditionality is an instrument in the post-conflict period to support, compel, and supervise authorities and reforms. This leverage can be used to press legislative changes, initiate and pull through concession reviews, and to take initiatives to increase transparency and inclusion of public in the resource management in general and the local population at the extraction site. Even if political will 
for reform is present, pressure from donors like the UN and World Bank can substantially help in pushing and speeding up the process as was the case in Liberia where the UN sanctions on timber pushed Liberia to set up a transparent and accountable system for forest and forest revenue management [8] [19]. At the same time, the financial support to make up delayed revenue flows due to (re)designing and implementing reforms, waiting for concession reviews, and delaying extraction start to make sure that contracts and assessments are fair and complete, can be crucial for these processes.

There is no single way to manage extraction of valuable natural resources in post-conflict countries, and many of the approaches that have been used have not yielded the desired results. This does not necessarily mean that the approaches were ill conceived; planning, implementation, and follow-up may have been inadequate, or there may have been unforeseen complications. Sometimes well-intentioned approaches may have unintended consequences. In the worst case, they may create new grievances that reignite conflict or cause new, low-level conflicts. Such results can sometimes be avoided through careful planning; in other cases, additional action may be needed to mitigate the consequences. Depending on the context, some or all of the approaches to extraction management covered in this article may be relevant to efforts to address the challenges extractive sector poses to peacebuilding.

\section{Acknowledgements}

The research for this article was supported by a Grant-in-Aid for Scientific Research on Priority Areas (21200047) of the Ministry of Education, Culture, Sports, Science and Technology of the Government of Japan, the AGS (Alliance for Global Sustainability) of the University of Tokyo, and Research Council of Norway (231757/F10). We thank Carl Bruch and Lynn Nygaard for extensive comments on earlier versions of this article. Kettenmann is an Associate with Beveridge \& Diamond; when the article was first drafted, she was a Research Associate at the Environmental Law Institute. The article represents views of the author and not Environmental Law Institute and Beveridge \& Diamond.

\section{References}

[1] Lujala, P. and Rustad, S.A. (2012) High-Value Natural Resources: A Blessing or a Curse for Peace? In: Lujala, P. and Rustad, S.A., Eds., High-Value Natural Resources and Peacebuilding, Routledge, London.

[2] IMF (2007) Angola: Selected Issues and Statistical Appendix. IMF Country Report, International Monetary Fund. www.imf.org/external/pubs/ft/scr/2007/cr07355.pdf

[3] Forrer, J.J. and Katsos, J.E. (2015) Business and Peace in the Buffer Condition. Academy of Management Perspectives, 29, 438-450. http://dx.doi.org/10.5465/amp.2013.0130

[4] Kolk, A. and Lenfant, F. (2015) Partnerships for Peace and Development in Fragile States: Identifying Missing Links. Academy of Management Perspectives, 29, 422-437. http://dx.doi.org/10.5465/amp.2013.0122

[5] Lujala, P. and Rustad, S.A. (2012) High-Value Natural Resources and Post-Conflict Peacebuilding. London, Routledge.

[6] Wennmann, A. (2011) Breaking the Conflict Trap? Addressing the Resource Curse in Peace Processes. Global Governance, 17, 265-279.

[7] Nichols, S.S., Lujala, P. and Bruch, C. (2011) When Peacebuilding Meets the Plan: Natural Resource Governance and Post-Conflict Recovery. Whitehead Journal of Diplomacy and International Relations, 12, 9-24.

[8] Beevers, M.D. (2015) Governing Natural Resources for Peace: Lessons from Liberia and Sierra Leone. Global Governance, 21, 227-246.

[9] Koubi, V., Spilker, G., Böhmelt, T. and Bernauer, T. (2014) Do Natural Resources Matter for Interstate and Intrastate Armed Conflict? Journal of Peace Research, 51, 227-243. http://dx.doi.org/10.1177/0022343313493455

[10] Haufler, V. (2015) Symposium on Conflict, Management, and Peace: Comments from an International Relations Scholar. Academy of Management Perspectives, 29, 461-468. http://dx.doi.org/10.5465/amp.2015.0158

[11] Lutundula Commission (2006) Assemblée Nationale Commission Spéciale Chargée de l'examen de la Validité des Conventions à Caractère Économique et Financier Conclues Pendant les Guerres de 1996-1997 et de 1998-2003. Rapport des travaux, République Démocratique du Congo. http://www.congomines.org/reports/210-rapport-lutundula-version-finale

[12] Lujala, P. (2010) The Spoils of Nature: Armed Civil Conflict and Rebel Access to Natural Resources. Journal of Peace Research, 47, 15-28. http://dx.doi.org/10.1177/0022343309350015 
[13] Lujala, P. (2009) Deadly Combat over Natural Resources: Gems, Petroleum, Drugs, and the Severity of Armed Conflict. Journal of Conflict Resolution, 53, 50-71. http://dx.doi.org/10.1177/0022002708327644

[14] Lujala, P. (2014) Valuable Natural Resources. In: Newman, E. and DeRouen, K., Eds., Routledge Handbook of Civil Wars, Routledge, New York.

[15] van der Ploeg, F. (2011) Natural Resources: Curse or Blessing? Journal of Economic Literature, 49, 366-420. http://dx.doi.org/10.1257/jel.49.2.366

[16] Rustad, S.A. and Binningsbø, H.M. (2012) A Price Worth Fighting for? Natural Resources and Conflict Recurrence. Journal of Peace Research, 49, 531-546. http://dx.doi.org/10.1177/0022343312444942

[17] Rustad, S.A., Lujala, P. and Le Billon, P. (2012) Building or Spoiling Peace? Lessons from the Management of High-Value Natural Resources. In: Lujala, P. and Rustad, S.A., Eds., High-Value Natural Resources and Peacebuilding, Routledge, London, 571-622.

[18] Le Billon, P. (2012) Contract Renegotiation and Asset Recovery in Post-Conflict Settings. In: Lujala, P. and Rustad, S.A., Eds., High-Value Natural Resources and Peacebuilding, Routledge, London.

[19] Altman, S.L., Nichols, S.S. and Woods, J.T. (2012) Leveraging High-Value Natural Resources to Restore the Rule of Law: The Role of the Liberia Forest Initiative in Liberia’s Transition to Stability. In: Lujala, P. and Rustad, S.A., Eds., High-Value Natural Resources and Peacebuilding, Routledge, London, 337-366.

[20] Gould, J. and Winters, M. (2012) Petroleum Blues: The Political Economy of Resources and Conflict in Chad. In: Lujala, P. and Rustad, S.A., Eds., High-Value Natural Resources and Peacebuilding, Routledge, London.

[21] Westermann-Behaylo, M.K., Rehbein, K. and Fort, T. (2015) Enhancing the Concept of Corporate Diplomacy: Encompassing Political Corporate Social Responsibility, International Relations, and Peace through Commerce. Academy of Management Perspectives, 29, 387-404. http://dx.doi.org/10.5465/amp.2013.0133

[22] Boege, V. and Franks, D. (2012) Reopening and Developing Mines in Post-Conflict Settings: The Challenge of Company-Community Relations. In: Lujala, P. and Rustad, S.A., Eds., High-Value Natural Resources and Peacebuilding, Routledge, London.

[23] Klein, D. and Joras, U. (2016) Natural Resources and Peacebuilding: What Role for the Private Sector? In: Bruch, C., Muffett, C. and Nichols, S.S., Eds., Governance, Natural Resources, and Post-Conflict Peacebuilding, Routledge, London, in press.

[24] Wiig, A. and Kolstad, I. (2011) Assigned Corporate Social Responsibility in a Rentier State: The Case of Angola. In: Lujala, P. and Rustad, S.A., Eds., High-Value Natural Resources and Peacebuilding, Routledge, London, 147-154.

[25] del Castillo, G. (2014) War-Torn Countries, Natural Resources, Emerging-Power Investors and the UN Development System. Third World Quarterly, 35, 1911-1926. http://dx.doi.org/10.1080/01436597.2014.971610

[26] Kaul, R., Heuty, A. and Norman, A. (2009) Getting a Better Deal from the Extractive Sector: Concessions Negotiation in Liberia, 2006-2008. A report to the Liberian Reconstruction and Development Committee Office of the President, Republic of Liberia, Revenue Watch Institute. https://www.opensocietyfoundations.org/sites/default/files/liberia_20090302.pdf

[27] Ofori, J.J.Y. and Lujala, P. (2015) Illusionary Transparency? Oil Revenues, Information Disclosure, and Transparency. Society \& Natural Resources, 28, 1187-1202. http://dx.doi.org/10.1080/08941920.2015.1024806

[28] Epremian, L., Lujala, P. and Bruch, C. (2016) High-Value Natural Resources and Transparency: Accounting for Revenues and Governance. In: Politics: Oxford Research Encyclopedias, in press.

http://politics.oxfordre.com/view/10.1093/acrefore/9780190228637.001.0001/acrefore-9780190228637-e-21?rskey=O qhqJs\&result $=23$

[29] Lujala, P. and Epremian, L. (2016) Transparency and Natural Resource Revenue Management: Empowering the Public with Information? In: Williams, A. and Le Billon, P., Eds., Corruption, Natural Resources and Development, Edward Elgar Publishing, in press.

[30] Le Billon, P. (2014) Natural Resources and Corruption in Post-War Transitions: Matters of Trust. Third World Quarterly, 35, 770-786. http://dx.doi.org/10.1080/01436597.2014.921429

[31] Sovacool, B.K. and Andrews, N. (2015) Does Transparency Matter? Evaluating the Governance Impacts of the Extractive Industries Transparency Initiative (EITI) in Azerbaijan and Liberia. Resources Policy, 45, 183-192. http://dx.doi.org/10.1016/j.resourpol.2015.04.003

[32] David-Barrett, E. and Okamura, K. (2016) Norm Diffusion and Reputation: The Rise of the Extractive Industries Transparency Initiative. Governance, 29, 227-246. http://dx.doi.org/10.1111/gove.12163

[33] EITI (2016) EITI, the Extractive Industries Transparency Initiative. Extractive Industries Transparency Initiative. https://eiti.org/

[34] EITI (2016) The EITI Standard 2016. EITI International Secretariat. https://eiti.org/files/english_eiti_standard_0.pdf 
[35] Shankleman, J. (2012) Mitigating Risks and Realizing Opportunities: Environmental and Social Standards for Foreign Direct Investment in High-Value Natural Resources. In: Lujala, P. and Rustad, S.A., Eds., High-Value Natural Resources and Peacebuilding, Routledge, London, 49-68.

[36] Voluntary Principles (2016) Voluntary Principles on Security and Human Rights. Voluntary Principles Initiative. http://www.voluntaryprinciples.org/

[37] Equator Principles (2016) Environmental and Social Risk Management for Projects. Equator Principles Association. http://www.equator-principles.com/

[38] IFC (2016) Sustainability at IFC. Environmental and Social Performance Standards and Guidance Notes. International Finance Corporation, World Bank Group. http://www.ifc.org 